\title{
Dimensions of Brand Equity affecting Consumption of Halāl/Harām Products: Moderating Role of Islamic Work Ethics
}

\author{
Ferryal Khan ${ }^{1}$, Areeba Sajid ${ }^{2}$, Sohail Kamran ${ }^{3 *}$ \\ ${ }^{1}$ Business Graduate of Fatima Jinnah Women University, Rawalpindi, Pakistan \\ ${ }^{2}$ Business Graduate of Fatima Jinnah Women University, Rawalpindi, Pakistan \\ ${ }^{3}$ Assistant Professor in the Department of Business Administration, \\ Fatima Jinnah Women University, Rawalpindi, Pakistan
}

\section{Keywords \\ Brand Image \\ Brand Awareness \\ Brand Equity \\ IWE \\ Consumption \\ Halāl/harām}

Received: $15-\mathrm{Jul}-19$

Accepted: $15-$ Oct-19

\begin{abstract}
This paper investigates impact of two dimensions of brand equity i.e., brand image and brand awareness on the consumption patterns of halāl/harām products when the consumers are aware of the Islamic Work Ethics (IWE) of the entity or firm from which they are buying the product. The data were collected from 307 respondents through online surveys and self-administered questionnaires based on a five-point Likert scale. Correlation and regression analyses were carried out to examine the effect of the dimensions of brand equity on consumption patterns of consumers. The findings suggest that both dimensions of brand equity have a positive impact on consumption patterns of consumers as found by regression analysis. The moderating effect of IWE was tested by multiple regression for the two dimensions of brand equity and it was found that IWE of the branding entity increases the strength of the relationship between the dimensions of brand equity and the consumption of the consumers. There are implications for marketers and policy makers. They should keep in mind that Muslims prefer halāl products and thus stress upon the importance of including haläl branded products in their list of promoted brands. The main contribution of this paper is that it examines how the IWE of the chosen firm ultimately affect the consumption of haläl/haräm products. The paper also provides managerial implications.
\end{abstract}

KAUJIE Classification: P1, T6

JEL Classification: M1, Z12

(C) 2019 JIBM. All rights reserved.

\section{INTRODUCTION}

Halāl products are the result of Islamic branding mainly produced by Muslim countries and the major target market for these halāl products are Muslims (Alserhan, 2010). However, halāl brands are also being offered to Muslim customers by many Multinational Corporations

\footnotetext{
*Corresponding author: Sohail Kamran

†Email: sohail@fjwu.edu.pk
} 
(MNCs) to cater the consumption needs of Muslims in various parts of the world. These companies include Nestle, L'Oreal, KFC, Unilever and McDonalds (Mohammad \& Quoquab, 2016). This has happened because Islam, with the number of its followers being up to 1.8 billion, is the 2nd largest religion in the world (Illsley, 2018). Haläl products and brands include categories such as edibles, cosmetics and pharmaceutical products. Haläl products are being expanded to different services including utilities, professional services, transportation, communication, which ultimately create a halāl value system for customers (Wilson, 2013). It is observed that haläl branding influences purchasing of haläl brands (Ali, Xiaoling, Sherwani, \& Ali, 2018). A few Islamic countries including Malaysia, Singapore and Indonesia have their own legal institutions that regulate the haläl food brands (Chaudry \& Riaz, 2004). Malaysia, Singapore, France, Indonesia and UK have also developed haläl certification and regulations to help consumers in identification of brands that are in accordance with the Islamic principles (Ismaeel \& Blaim, 2012).

Contrary to the availability of halāl products, harām products are also available at the marketplace, but it is forbidden to Muslims to consume the harām products. Some of the harām products include addictive drugs, wine and alcohol, pork and adult toys. Harām services may include dancing and prostitution (Mohammad \& Quoquab, 2016). Muslim countries such as Malaysia, Turkey, Indonesia and the Arab Gulf countries have prohibited advertisement of harām or controversial products like alcohol, drugs, cigarettes and condoms (Waller, Fam, \& Erdogan, 2005). Islamic teachings put great emphasis on doing good deeds and engaging in halāl and lawful activities in order to attain goodness in this world and in the world hereafter and for the betterment of humanity (Ali \& Al-Kazemi, 2007). Mohammad and Quoquab (2016) state that Muslims' consumption must be according to the divine teachings of Islam. The study by Asnawi, Sukoco, and Fanani (2018) found that perceived behavioral control and religiosity play vital role in deciding upon the consumption of halāl products in international chain restaurants. Likewise, Ahmed, Najmi, Faizan, and Ahmed (2019) found that haläl food products influence consumer's willingness to pay more for that product. Shahid, Ahmed, and Hasan (2018) did research on haläl cosmetic products and found that awareness about halāl products and haläl certifications increases the consumer's haläl consumption of that product.

The studies regarding halāl branded products consumption have been carried out in countries such as Malaysia, Turkey, Indonesia. But, the researchers have generally ignored to investigate the consumption of hala $l$ branded products in correspondence with the IWE of the firms or entity from which consumers are buying the product. This warrants a study on the aforementioned issue to ascertain how dimensions of brand equity affect consumption patterns of haläl/harām products among Muslim consumers when they are aware of the IWE of the firm from which they are buying the product. Moreover, according to best of our knowledge, work on the concepts of haläl/harām brands consumption among Muslim consumers has not been investigated in detail in the prior researches. Therefore, this study takes the respondent's sample from Pakistan and investigates impact of two dimensions of brand equity i.e., brand image and brand awareness on the consumption patterns of haläl/harām products when consumers are aware of the IWE of the firm from which they are 
buying the product. The main reason for selecting this topic was that most of the research on brand equity was carried out in western countries context. A little research is available on dimensions of brand equity and brand awareness on the consumption patterns of haläl/harām products when the consumers are aware of the IWE of entity/firm from which they are buying the product.

The next section of the paper encompasses literature review; it is followed by methodology. Subsequently, we provide study findings and discussion, and conclusions of the study.

\section{LITERATURE REVIEW}

Theory of Planned Behaviour (TPB) has effectively been cited by many scholars to determine the consumer behavior (Wibowoa, 2005). TPB is the elaboration of the Theory of Reasoned Action (TRA) as it doesn't integrate the volition of control (the extent to which a behavior can be executed straightforwardly) in determining a behavior (Tarkiainen \& Sundqvist, 2005). In 1991, Ajzen said that by adding behavior control assessment the behaviour could be more accurately forecasted. Moreover, the resources and opportunities available to a customer also present very important points in formulating the customer's behavior (Ajzen, 1991). Behavioral control is a consumers' response towards the opportunities they possess (Tarkiainen \& Sundqvist, 2005). TPB aims to incorporate the attitude that is not totally under our will. Perceived Behavioural Control is thus included in TPB, with the two deciding factors of intention mentioned in the TRA (Klobas, 2000). Intention can be stated to be a combination of attitude, norms and perceived behavioural control (Ajzen, 1991). Attitude towards a behaviour shows a person's positive/adverse judgments' of accomplishing a particular behaviour. The more positive the attitude towards the behaviour, the stronger should be a person's intention of performing certain action (Armitage, 2001).

\section{Brand Awareness}

Brand awareness is a main constituent of the models which explain brand equity (Aaker, 1991) and is an important but often times disregarded facet of consumer based brand equity (Jenni \& Faulkner, 2017). It is the requisite first step in the development of brand equity of newly established brands (Keller, 1993). It helps in the selection of alternatives (Keller, 1993) and influences brand equity among consumers (Sasmita \& Suki, 2015) by facilitating choice (Keller, 1993), reducing risk while purchasing the product (Aaker, 1996; Keller \& Lehmann, 2003) and building association in memory between the brand name and product category (Heckler, Keller, Houston, \& Avery, 2014; Keller, 1993). Brand awareness constitutes brand recognition and brand recall performance. Brand recognition requires that the consumer has heard or seen the brand and as a result recognizes the brand immediately when provided with a stimulus such as a prompt reminder and brand recall requires remembering a particular brand when specified with a product category (Keller, 1993; Keller, 2008). It has been stated that brand recall is seen to be the most commonly used measure of brand awareness (Esch, Langner, Schmitt, \& Geus, 2006).

Brand awareness helps in creating a brand attitude, which ultimately leads to an intention to buy (Rossiter \& Percy, 1987). This is because brand awareness has a direct impact on 
brand equity (Pouromid \& Iranzadeh, 2012) as it is one of the dimensions of brand equity with the strongest correlation (Sasmita \& Suki, 2015). Keller (1993) and Kapferer (2004) emphasize that brand awareness has a significant correlation with and helps in the formation of brand image. Aaker (1991) explained that brand awareness helps in the development of brand equity. It has also been seen that brand awareness indirectly affects the current purchases of consumers (Esch et al., 2006).

\section{Brand Image}

Brand image as explained by Dobni and Zinkhan (1990) refers to the meanings which consumers associate with a brand name. According to Nandan (2005), consumers create an image regarding a brand in accordance with their knowledge, beliefs and perceptions that they might have related to the brand. Aaker (1991) describes brand image as a set of associations that the customer significantly relates with a brand. This image remains in consumers mind (Sherry, 2005) and helps them in making purchase decisions (Aaker, 1991). Based on Keller's study (1993), marketing campaigns are helpful in creating a positive brand image by linking brand association and consumers' perceptions about the brand. Magid and Dena (2006) observed that the brand image includes consumer responses to a brand name and sign which also entitles the quality of product. Aaker (1991) and Rory (2000) found that with the creation of positive brand image, customers' satisfaction is increased and they increase the brand usage and also recommend it to others.

According to Keller (1993), if the benefits that are provided by the product satisfy the needs and desires of customers, then it would create a positive brand image and help in maintaining the valuable relationship between the brand and consumers (Chaudhuri \& Holbrook, 2001). Thus, brand image affects the purchasing behavior and consumption patterns of consumers. It has been seen that brand image has a direct impact on the current purchases (Esch et al., 2006). Moreover, according to Severi and Ling (2013) a much stronger brand image has the power to overwrite the marketing messages of competing brands.

\section{Brand Equity}

Brand equity can be described as the extent of awareness that the consumers have about a certain brand of the product or service (Keller, 2008). This concept first time was acknowledged by Farquhar (1989) who asserts that brand equity was a mean of adding additional value to a product. Aaker (1991) highlighted the importance of brands by stating that majority of the companies might just purchase existing brands rather than spending cost on developing a new brand from scratch. Brand equity results from consumers' expectations of what the brand would deliver in comparison with its competitors (Lassar, Mittal, \& Sharma, 1995). Companies having strong brand equity can compete against their competitors (Severi \& Ling, 2013) and influence consumers to pay premium for their brand (Lassar et al., 1995). Keller (1993) has explained that brand equity is a concept that is specifically derived from the point of view of an individual consumer. In accordance with Keller's (1993) concept, the two motivations for studying brand equity include evaluating (I) financial value of the brand and (II) the results of its marketing efforts. These two motivations are referred to as financial 
and customer perspective respectively (Lassar et al., 1995; Severi \& Ling, 2013). According to Kotler (2010) brand name plays an important role in creating brand equity through the effective use of marketing efforts of advertising and promotion. It has been observed that consumers who are committed to certain brands view changes in the brand as a potential threat to their relationship with the brands and this high commitment is only possible through brand equity, as Jeon (2017) had indicated.

Brand awareness and brand image can be used in the measurement of brand equity (Keller, 1993). However, Aaker (1991) has provided other factors related to evaluating brand equity, which include brand association, brand awareness, brand loyalty and perceived quality. It is suggested that although all of these factors can be considered as dimensions of brand equity and they still hold great importance as being independent concepts (Keller, 1993). Keller (1993) found that Customer Based Brand Equity (CBBE) occurs when the consumer is acquainted and informed about the brand and holds a good opinion of the brand in his/her mind. One of the most influential models that affects customers and their purchase decisions is Keller's CBBE model (1993) as the customer's distinct response to the marketing efforts directed towards that brand in comparison with the competing brands. According to Sallam (2016), brand equity influence customers as it has a positive effect on consumer choice.

\section{IWE}

IWE refer to the virtues during workbased on the Injunctions of the Holy Qur'ān and Sunnah (Alhyasat, 2010) and emphasize the concepts of halāl, harām and niyyah (Mohammad \& Quoquab, 2016). IWE are the principles that illustrate what Muslims are allowed to do in the light of Holy Qur'ān and Sunnah of Prophet (P.B.U.H) (Hashi, 2011). IWE involve all expectations related to one's attitude at workplace and it comprises of all the struggles, commitments, devotions and responsibilities one contributes in an organization. Organizations that apply principles of Islam at workplace ultimately contribute to welfare and prosperity as a whole (Jalil, Azam, \& Rahman, 2010).

Islam has given equal importance to both physical and non-physical work and has valued those who support others at work field as long as it is virtuous (Possumah, 2013). Islam offers big rewards to those who show transparency and morality in their business dealings (Owahian \& Ali, 2008). In Islam, decision must be based on the principles of consultations $(s h \bar{u} r a ́)$, transparency $(a l$-șidq), trustworthiness (al-amānah), impartiality ( $a l$ - 'adl), collaboration (al-ta' $\bar{a} w u n)$ and quality (al-ikhlās) (Khan, 2013). According to Mutahhari (1985), Islam supports two types of justice. One is divine and the other is human. Level of good deed requires an individual to escape evils when accomplishing the assigned task. It is also mandatory to build harmonious environment in which responsibilities can be carried-out effectively and disparity determined (Al-Maududi, 1967). Kamal (1985) claimed that firm belief boosts production and performance. If any business wants to grow and establish its unique and permanent position in the world, it would only be possible, if both employers and employees have strong and friendly relationships (Bhattacharya, 2012). By adopting IWE, organizations can shape their employees into a better persons (Zul Kernain \& Norhasniah, 2019). The first and foremost obligation of the employer is to preserve the wellbeing and 
welfare of its employees such as paying good salary and flexible timing (Ali, Noorin, \& Achour, 2018). The second responsibility is accepting the privileges which Islam has granted to employees and no one can snatch from employees. No employer can treat its employees on the basis of race, skin color, caste and ethnicity (Ali et al., 2018). Wilson (2006) has claimed that IWE have its inimitable contribution in the business management and work-settings. Islam has provided knowledge related to every aspects business including how one should behave in a work-setting (Ali, 1992).

\section{Consumption of Haläl Products}

Hala $\bar{l}$ means permissible and acceptable while harām is considered as illegal and prohibited in Islam (Rosly, 2010). Islamic teachings clearly indicated what is haläl and haräm for Muslims (Ambali \& Bakar, 2014). Now, most of the Islamic countries have established halāl logistic suppliers and have developed a halāl supply-chain to fulfill the increasing demand from the producer of halāl product as to maintain the sustainability of halāl product, it must be moved by the right person with the right procedure (Ngah, Zainuddin, \& Thurasamy, 2013). Such procedures include halāl logo which is used to indicate that particular product is halāl (Pettinger, Holdsworth, \& Gerber, 2004). Introducing halāl logo has enhanced the awareness among Muslims that this particular product is permissible for eating and consuming according to the teachings of Islam (Shafie \& Othman, 2006). Sungkar (2010) indicated the factors that impact consumers purchasing of haläl product. These include consumers' firm belief, trust upon halāl logos, knowledge and awareness about halāl consumption and increasing concern about health related issues. Muslims have intense desire of associating themselves with the consumption of haläl products, and they strictly follow the pattern of consuming halāl and at the same time they try to avoid harām (Suki \& Salleh, 2017). Many researchers maintain that many haläl-conscious Muslim customers are more resistant towards risk and they are more loyal towards halāl brands and thus their switching to other conventional brands is low (Siala, 2013).

\section{Theoretical Framework}

The theory of planned behaviour can be applied to current study. With brand awareness and brand image being the dimensions of brand equity and IWE, all acting as variables that impact the intention of the consumer by influencing the attitude, norms and behavioural control of the consumer, thus eventually shaping up the behaviour of the consumer towards consumption of a particular product. Figure 1 represents the theoretical framework for this study. In this study, two dimensions of Brand Equity i.e., Brand Awareness and Brand Image have been used as Independent Variables (IVs); consumption is the Dependent Variable (DV) and IWE is taken as a moderator that will moderate the relationship between IV and DV.

\section{Hypothesis}

H1: Brand Awareness has a positive impact on Consumption.

H2: Brand Image has a positive impact on Consumption.

H3: IWE of the branding entity increase the strength of the relationship between brand 
awareness and consumption of the branded products.

H4: IWE of the branding entity increase the strength of the relationship between brand image and consumption of the branded products.

\section{METHODOLOGY}

The purpose of this study was to ascertain impact of the dimensions of brand equity on the consumption of halāl or harām products. The data were collected from 307 respondents through five-point Likert scale questionnaire. The data were mainly collected through an online survey, but 37 responses were gathered from self-administered questionnaires because those respondents were not conformable to complete an online survey. We ensured anonymity to our respondents by including a written statement in the questionnaire clarifying to them that their personal information would not be shared with anyone and the data was being collected solely for completing the current research.

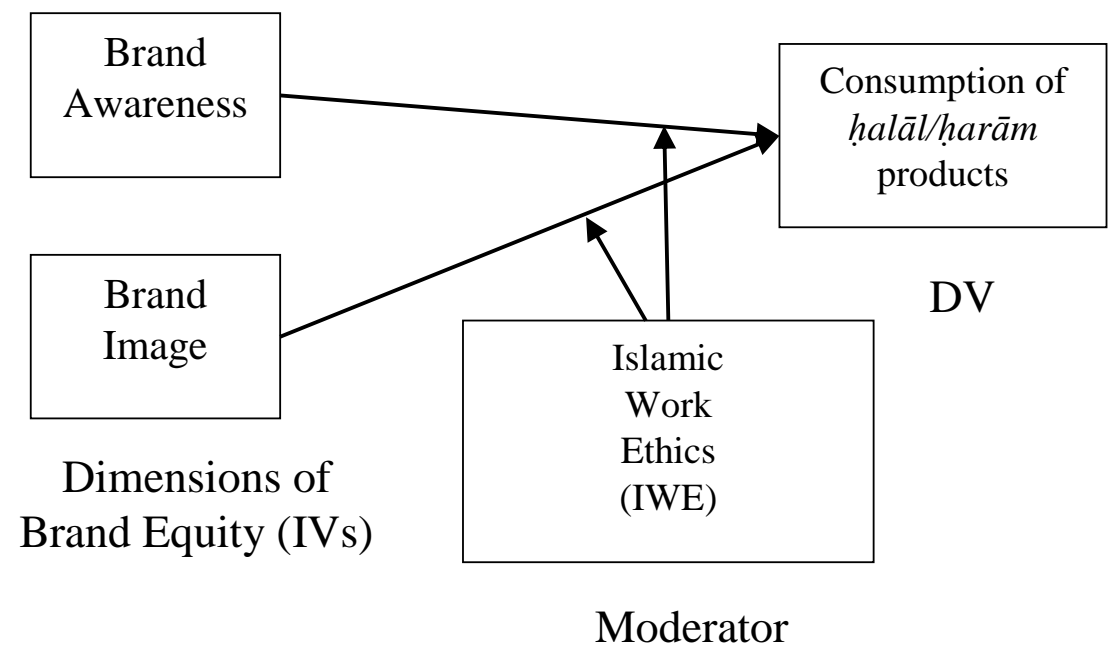

FIGURE 1. Theoretical framework

The respondents included 117 males (38.1\%), 173 females $(56.4 \%)$ and 17 people who preferred not to state their gender $(5.5 \%)$. The respondents were involved in the consumption of branded products (halāl/haräm). They belonged to different occupations such as, students, self-employed, government employees and unemployed. Respondents' qualifications varied from $\mathrm{PhD}$ to matriculate levels, who were residing in both rural (17.95) and urban areas $(82.1 \%)$. The religion of the 303 respondents was Islam (98.7\%) with the exception of 4 respondents i.e., 2 belonged to Sikhism $(0.7 \%)$ and 2 belonged to Hinduism $(0.7 \%)$. Family income of the respondents ranged from being $<10,000(14,4.6 \%), 10,000-30,000$ (31, $10.1 \%)$ to $30,000-60,000(98,31.9 \%)$ and $>60,000(164,53.4 \%)$. Random sampling has been used in the study. The respondents belonged to different age groups like being 19 years or less $(23,7.5 \%), 20-24$ years $(140,45.6 \%), 25-34$ years $(69,22.5 \%), 35-44$ years $(40,13 \%)$, $45-55$ years $(20,6.5 \%)$ and 55 years and above $(15,4.9 \%)$. A detailed description of the respondents' characteristics is provided in Table 1.

Respondent's choice of the branded product was influenced due to the reasons such as price $(41,13.4 \%)$, brand name $(72,23.5 \%)$, variety $(81,26.4 \%)$, service $(78,25.4 \%)$, convenience 
$(22,7.2 \%)$ and home delivery $(13,4.2 \%)$. The consumption patterns of the respondents ranged from 1-2 times $(99,32.2 \%), 2-4$ times $(59,19.2 \%), 4-6$ times $(57,18.6 \%)$ and more than 6 times $(92,30 \%)$. The most sought after brand in the food category was KFC (44, $14.3 \%)$, followed by McDonalds (24, 7.8\%), K\&Ns (14, 4.6\%), Pizzahut (9, 2.9\%), Hardees $(6,2 \%)$ and Nestle $(12,3.9 \%)$. In the cosmetics and fragrances category, the most sought after brands were Maybelline (3, 1\%), Chanel (10, 3.3\%), J. (17, 5.5\%), Medora (6, 2\%), Bonanza (5, 1.6\%), L'Oreal (7, 2.3\%), Hugo Boss (5, 1.6\%), Khaadi $(3,1 \%)$, MAC $(6,2 \%)$, Revlon (4, 1.3\%), Huda beauty $(6,2 \%)$. Other respondents listed their preferences among the brands in the others category $(126,41 \%)$. This category included brand names such as New Yorker Pizza, Nancy Perfumes, ZQ365, Tasty foods, Tehzeeb, Burger King and many more. These results have been shown in the Table below:

TABLE 1

Respondents Demographical Details

\begin{tabular}{llll}
\hline \hline Demographics & Categories & Frequency & Percentage \\
\hline Gender & Male & 117 & 38.1 \\
& Female & 173 & 56.4 \\
Family Income & Prefer not to say & 17 & 5.5 \\
& $<10,000$ & 14 & 4.6 \\
& $10,000-30,000$ & 31 & 10.1 \\
Age & $30,000-60,000$ & 98 & 31.9 \\
& $>60,000$ & 164 & 53.4 \\
& 19 years or less & 23 & 7.5 \\
20-24 years & 140 & 45.6 \\
Qualification & 25-34 years & 69 & 22.5 \\
& 35-44 years & 40 & 13 \\
& 45-54 years & 20 & 6.5 \\
Residence & 55 years and above & 15 & 4.9 \\
Religion & PhD. & 21 & 6.8 \\
& Post-Graduate & 91 & 29.6 \\
& Graduate & 86 & 28 \\
Occupation & Undergraduate & 92 & 30 \\
& Matriculate & 17 & 5.5 \\
& Rural & 55 & 17.9 \\
& Urban & 252 & 82.1 \\
& Islam & 303 & 98.7 \\
& Sikhism & 2 & 0.7 \\
& Hinduism & 2 & 0.7 \\
& Student & 126 & 41 \\
& Self-Employed & 54 & 17.6 \\
& Company Employee & 90 & 29.3 \\
& Government Employee & 11 & 3.6 \\
& Not Employed & 26 & 8.5 \\
\hline
\end{tabular}


TABLE 1 Continue

\begin{tabular}{|c|c|c|c|}
\hline Demographics & Categories & Frequency & Percentage \\
\hline \multirow[t]{6}{*}{ Reason for Spending on Brand X } & Price & 41 & 13.4 \\
\hline & Brand Name & 72 & 23.5 \\
\hline & Variety & 81 & 26.4 \\
\hline & Service & 78 & 25.4 \\
\hline & Convenience & 22 & 7.2 \\
\hline & Home Delivery & 13 & 4.2 \\
\hline \multirow[t]{4}{*}{ Frequency of Consumption } & $1-2$ times & 99 & 32.2 \\
\hline & 2-4 times & 59 & 19.2 \\
\hline & 4-6 times & 57 & 18.6 \\
\hline & More than 6 times & 92 & 30 \\
\hline \multirow[t]{18}{*}{ Brand X } & $\mathrm{KFC}$ & 44 & 14.3 \\
\hline & McDonalds & 24 & 7.8 \\
\hline & $\mathrm{K} \& \mathrm{Ns}$ & 14 & 4.6 \\
\hline & Pizzahut & 9 & 2.9 \\
\hline & Hardees & 6 & 2 \\
\hline & Nestle & 12 & 3.9 \\
\hline & Maybelline & 3 & 1 \\
\hline & Chanel & 10 & 3.3 \\
\hline & J. & 17 & 5.5 \\
\hline & Medora & 6 & 2 \\
\hline & Bonanza & 5 & 1.6 \\
\hline & L'Oreal & 7 & 2.3 \\
\hline & Hugo Boss & 5 & 1.6 \\
\hline & Khaadi & 3 & 1 \\
\hline & MAC & 6 & 2 \\
\hline & Revlon & 4 & 1.3 \\
\hline & Huda & 6 & 2 \\
\hline & Others & 126 & 41 \\
\hline
\end{tabular}

A questionnaire was utilized to collect data from respondents. A brief introduction about the study aims was provided in the survey form to familiarize the respondents regarding the concepts used in the survey. The online survey was designed on a 5-point Likert scale which included options from $1=$ strongly disagree, $2=$ disagree, $3=$ neutral, $4=$ agree, and $5=$ strongly agree, while the various items for the Likert scale were adapted from the previous researches with little modifications like names of the products were replaced by the term Brand $X$ and all of the data was gathered on the basis of this scale. Section 1 and 2 constituted an introduction of the study and the demographics, while section 3 till 7 were based on the variables under study ranging from brand awareness, brand image, IWE of the company providing the branded product, consumption of the consumers regarding the haläl and harām 
products and some general information about the brand chosen by the respondents. The online survey and self-administered questionnaire comprised 33 items in total, also including demographic questions.

First, the demographics such as age, gender, family income, educational level, occupation, religion and region were collected from the respondents. Second, brand awareness was measured through five items (i) I am familiar with brand $\mathrm{X}$, (ii) I can recognize brand $\mathrm{X}$ quickly among other competing brands, (iii) The characteristics of brand X come to my mind quickly. These three items were adapted from Ahmad and Butt (2012); while (iv) I can quickly recall brand $\mathrm{X}$ when someone mentions food/cosmetics/fragrances, and (v) I know what brand X looks like were adapted from Yoo and Donthu (2001). Third, brand image was measured through six items (i) brand $\mathrm{X}$ has a unique image as compared to other competing brands was adapted from Ahmad and Butt (2012), (ii) Brand X has sophisticated image and (iii) Brand X is well established were adapted from Severi and Ling (2013). While (iv) Brand $\mathrm{X}$ awakens good memories for me and (v) Brand X shows me what I were adapted from Cho, Fiore, and Russell (2015) and (vi) Brand X fits my personality was adapted from Lassar et al. (1995). Fourth, IWE was measured through five items (i) Laziness is vice, (ii) Good work benefits both one's self and others, (iii) Dedication to work is a virtue, (iv) One should carryout work to the best of one's ability, and (v) One should constantly work hard to meet responsibilities have been adapted from Ali (1992).

Finally, consumption was measured through seven items (i) I will always find the haläl's Logo on the brand $\mathrm{X}$ before consumption, (ii) The ingredients of Brand $\mathrm{X}$ are very important have been adapted from Rahman, Asrahaghighi and Rahman (2015) (iii) Islamic consumers have the right to report on any fraud haläl logo presented by manufacturers, (iv) Pak-Halāl Food Authority must take action on all manufacturers who do not follow the halāl standard, (v) My selection of Brand X is influenced by others even though the products do not have the halāl logo, (vi) All consumer brands must get the haläl's verification and (vii) I do not purchase Brands that I do not believe to be haläl; all adapted from Aziz and Chok (2012).

Statistical Package for Social Sciences (SPSS) version 20 was used for all of the calculations of reliability, normality, correlation and regression. Among the lists of analysis that has been conducted include reliability analysis, normality tests (to see if the data is normally distributed or not) and correlation and regression analyses conducted for determining the relationship among the variables as well as to study the impact of brand equity on consumption through two dimensions of brand equity i.e., brand awareness and brand image, while keeping in view the role of IWE as a moderator.

\section{FINDINGS AND RESULTS}

\section{Reliability}

The reliability analysis was carried out to check the reliability and validity of the items of the questionnaires that were adapted from the various researchers. Cronbach alpha of brand awareness was $=0.914$, brand image $=0.884$, IWE $=0.765$, consumption $=0.6$ and finally the cronbach alpha for 23 items of the whole questionnaire was 0.901 . This depicted that the 
alpha values were equal to or greater than 0.6 , ultimately representing a reliable questionnaire (Table 2).

TABLE 2

Reliability

\begin{tabular}{lll}
\hline \hline Variable & Cronbach Alpha & No. of Items \\
\hline Brand Awareness & 0.914 & 5 \\
Brand Image & 0.884 & 6 \\
IWE & 0.765 & 5 \\
Consumption & 0.6 & 7 \\
\hline \hline
\end{tabular}

\section{Normality}

The normality of the data was determined through skewness and kurtosis in SPSS. For the skewness the values were calculated to be $-1.667,-1.343,-1.325$ and -1.651 for brand awareness, brand image, IWE and consumption, respectively. The kurtosis was determined to be 3.127, 2.827, 2.628 and 5.839 for brand awareness, brand image, IWE and consumption, respectively. As the values for skewness were negative this shows that the data was negatively skewed, and as the values of skewness are less than -1 therefore, the data is skewed. The interpretation for kurtosis is that the values have to lie in between \pm 3 and as the statistics show that brand awareness, brand image and IWE are within the range for kurtosis, but the value for consumption is greater than 3 which shows that the data has a positive kurtosis and thus has a peaked representation.

TABLE 3

Normality

\begin{tabular}{lll}
\hline \hline Variable & Skewness & Kurtosis \\
\hline Brand Awareness & -1.667 & 3.127 \\
Brand Image & -1.343 & 2.827 \\
IWE & -1.324 & 2.628 \\
Consumption & -1.651 & 5.839 \\
\hline \hline
\end{tabular}

\section{Correlation and Regression}

The values show that $R=0.312, p=0.000$ for brand awareness. While regression shows $\beta=$ $0.312, t=5.742, F=32.969, p=0.000$ and adjusted $R^{2}=0.095$ as shown in Tables below.

Beta has a value which is $-1 \leq \times \leq 1, t>2$, and $p<0.01$. $R^{2}$ shows that brand awareness has caused $9.5 \%$ variation in consumption without IWE. The values of correlation and regression show that there is a moderate linear relation between brand awareness and consumption. All of this information provide support for H1. So, H1 is accepted i.e., H1: Brand Awareness has a positive impact on Consumption. 
TABLE 4

Brand Awareness Correlation

\begin{tabular}{llll}
\hline \hline & & Brand Awareness & Consumption \\
\hline Brand Awareness & Pearson Correlation & 1 & $0.312^{* *}$ \\
& Sig (2-tailed) & & 0.000 \\
& $N$ & 307 & 307 \\
Consumption & Pearson Correlation & $0.312^{* *}$ & 1 \\
& Sig (2-tailed) & & 0.000 \\
& $N$ & 307 & 307 \\
\hline \hline
\end{tabular}

TABLE 5

Brand Awareness Regression Values

\begin{tabular}{llllll}
\hline \hline Variable & Adjusted $R^{2}$ & Beta & $t$ Value & $F$ Value & $p$ Value \\
\hline Brand Awareness & 0.095 & 0.312 & 5.742 & 32.969 & 0.000 \\
\hline \hline
\end{tabular}

The values show that $R=0.341, p=0.000$ for brand image. While regression shows $\beta=$ $0.341, t=6.331, F=40.081, \quad=0.000$ and adjusted $R^{2}=0.113$ as shown in Table.

Beta has a value which is $-1 \leq \times \leq 1, t>2$, and $p<0.01$. $R^{2}$ shows that brand awareness has caused $11.3 \%$ variation in consumption without IWE. The values of correlation and regression show that there is a moderate linear relation between brand image and consumption. All of this information provide support for $\mathrm{H} 2$ so it is accepted which states that brand Image has a positive impact on consumption.

TABLE 6

Brand Image Correlation

\begin{tabular}{llll}
\hline \hline & & Brand Image & Consumption \\
\hline Brand Image & Pearson Correlation & 1 & $0.341^{* *}$ \\
& Sig (2-tailed) & & 0.000 \\
& $N$ & 307 & 307 \\
Consumption & Pearson Correlation & $0.341^{* *}$ & 1 \\
& Sig (2-tailed) & 0.000 & \\
& $N$ & 307 & 307 \\
\hline
\end{tabular}

TABLE 7

Brand Image Regression Values

\begin{tabular}{llllll}
\hline \hline Variable & Adjusted $R^{2}$ & Beta & $t$ value & $F$ value & $p$ value \\
\hline Brand Image & 0.113 & 0.341 & 6.331 & 40.081 & 0.000 \\
\hline \hline
\end{tabular}

The correlation values for IWE were $R=0.463, p=0.000$ for brand awareness. While multiple regression was done through moderation testing and has been shown in the Tables below. 
TABLE 8

IWE Correlation

\begin{tabular}{llll}
\hline \hline & & IWE & Consumption \\
\hline IWE & Pearson Correlation & 1 & $0.463^{* *}$ \\
& Sig (2-tailed) & & 0.000 \\
& $N$ & 307 & 307 \\
Consumption & Pearson Correlation & $0.463^{* *}$ & 1 \\
& Sig (2-tailed) & 0.000 & \\
& $N$ & 307 & 307 \\
\hline \hline
\end{tabular}

Table 9 represents the values of the effect that brand awareness has on consumption of branded products with IWE as the moderating variable. The model fit is represented by the value of $F(3,303)=39.1595, p<.001, R^{2}=.2812$. It has been seen from the obtained values that brand awareness, consumption and IWE combined together show $28 \%$ of variation in consumption patterns. The effect of IWE on consumption shows that one unit change in IWE brings 100 units change in consumption $(b=1.001, t(303)=7.1494, p=.000)$. The effect of brand awareness on consumption brought 77 units change in consumption $(b=.7689, t$ (303) $=5.2666, p=.000$ ). The interaction term (the product of brand awareness and IWE) shows a significant level while the beta being negative shows a negative and significant moderation effect of consumption $(b=-0.1719, t(303)=.0349, p=.000)$. As the $p$ value is less than 0.05 so it comes out to be significant and thus the hypothesis $\mathrm{H} 3$ is accepted. This means that in the presence of high level of IWE, the impact of brand awareness on the consumption would increase. Thus we can say that $\mathrm{H} 3$ is accepted i.e., IWE of the branding organization increases the strength of the relationship between brand awareness and consumption of the branded products."

TABLE 9

Moderation Analysis with Brand Awareness

\begin{tabular}{lllllll}
\hline \hline & $R$ & $R^{2}$ & $F$ & df1 & df2 & $p$ \\
\hline & .5303 & .2812 & 39.5195 & 3.0000 & 303.0000 & .0000 \\
\hline & & $\beta$ & SE & $t$ & $p$ & \\
\hline 1 & Brand Awareness (X) & .7689 & .1460 & 5.2666 & .000 & \\
2 & IWE (W) & 1.001 & .1400 & 7.1494 & .000 & \\
3 & Interaction term $\left(\mathrm{X}^{*} \mathrm{~W}\right)$ & -0.1719 & .0349 & -4.9274 & .000 & \\
\hline \hline
\end{tabular}

$R^{2}$ change $=.2812, F(3,303)=39.5195, p=.0000$

Interaction term = Brand Awareness $*$ IWE (Independent Variable*Moderator)

Dependent Variable: Consumption

Table 10 represents the values of the effect that brand image has on consumption of branded products with IWE as the moderating variable. The model fit is represented by the value of $F(3,303)=47.1096, p<.001, R^{2}=.3181$. It has been seen from the obtained values that brand image, consumption and IWE combined together, show $32 \%$ of variation in consumption patterns. The effect of IWE on consumption shows that one unit change in IWE brings 118 units change in consumption $(b=1.1820, t(303)=8.3566, p=.000)$. The effect 
of brand image on consumption brought 112 units change in consumption $(b=1.1212, t(303)$ $=6.7328, p=.000$ ). The interaction term (the product of brand image and IWE) shows a significant level while the beta being negative shows a negative and significant moderation effect of consumption $(b=-0.2416, t(303)=-6.3344, p=.000)$. As in this case the $p$ value is less than 0.05 so it comes out to be significant and thus the hypothesis $\mathrm{H} 4$ is accepted. This means that in the presence of high level of IWE, the impact of brand image on the consumption would increase. Thus we can say that $\mathrm{H} 4$ is accepted i.e., IWE of the branding organization increases the strength of the relationship between brand image and consumption of the branded products.

TABLE 10

Moderation Analysis with Brand Image

\begin{tabular}{lllllll}
\hline \hline$R$ & $R^{2}$ & $F$ & df1 & df2 & $p$ \\
\hline & .5640 & .3181 & 47.1096 & 3.0000 & 303.0000 & .0000 \\
\hline 1 & Brand Image $(\mathrm{X})$ & 1.1212 & .1665 & 6.7328 & .000 & \\
2 & IWE $(\mathrm{W})$ & 1.1820 & .1414 & 8.3566 & .000 & \\
3 & Interaction term $\left(\mathrm{X}^{*} \mathrm{~W}\right)$ & -0.2416 & .0381 & -6.3344 & .000 & \\
\hline \hline
\end{tabular}

$R^{2}$ change $=.3181, F(3,303)=47.1096, p=.0000$

Interaction term $=$ Brand Image $*$ IWE (Independent Variable*Moderator)

Dependent Variable: Consumption

\section{DISCUSSION AND CONCLUSION}

This research examined the impact of two dimensions of brand equity i.e., brand image and brand awareness on the consumption patterns of halāl and haräm products when the consumers are aware of the IWE of selling firm from which they are buying the product in Pakistani context. The findings suggest that both dimensions of brand equity have a positive impact on consumption patterns of consumers as found by regression analysis. The moderating effect of IWE was tested by multiple regression for the two dimensions of brand equity and it was found that IWE of the branding firm increases the strength of the relationship between the dimensions of brand equity and the consumption of the consumers. A brief summary of the accepted hypotheses is given in the form of the Table 11.

TABLE 11

Summary of Research Findings

\begin{tabular}{ll}
\hline \hline Hypothesis & Result \\
H1: Brand Awareness has a positive impact on Consumption. & Accepted \\
H2: Brand Image has a positive impact on Consumption. & Accepted \\
H3: IWE of the branding firm increases the strength of the relationship between & Accepted \\
brand awareness and consumption of the branded products. & \\
H4: IWE of the branding firm increase the strength of the relationship between & Accepted \\
brand image and consumption of the branded products. & \\
\hline
\end{tabular}

The findings of the current research are somewhat similar to the research done by Ambali and Bakar (2014). They also found out that haläl brand's awareness was an important determinant in the choices that Muslims make regarding consumption and thus affected their 
consumption patterns. Whereas, in the study of Rios, Riquelme, and Abdelaziz (2014) it was found out that brand awareness in the form of familiarity and its link with the brand preference was not that strong and this was because the research was being affected by those people that were not that familiar with the product and resorted to answering according to the nature of the questions. Muslims essentially are very much conscious about the products that they consume and whether the same is are haläl or not. This is due to their religious belief that ultimately makes the Muslim consumers to buy and consume only those products that are considered to be haläl in Islam. Therefore, it can be stated that awareness of haläl brand and brand image, along with IWE, play an important role in the selection and consumption of halāl products.

The results from this study show that the consumption of the people is affected by knowledge of the branded products as well as the image of those brands in the minds of the consumers. The consumption of the brands is also affected by the IWE of the firm or entity from which the consumers are buying the products. Therefore, it is crucial for the marketers and policy makers to realize that they should focus on creating brand awareness and brand image of the products in a way that they are not being portrayed as Harām otherwise the Muslim customers would shun buying and consumption of those brands.

The present study mainly focused on the consumption patterns of Muslims by applying the concept of halāl and harām and IWE of the selling firm. Although a number of individuals of other religions (Sikhs and Hindus) also participated in the survey, but their numbers were very few (4 out of a total sample of 307) and most of the respondents were Muslims. Thus, future research may also be conducted to explore the reactions of Non-Muslims towards the concepts of IWE and haläl/harām products, not only in Pakistan but world-wide as well. Moreover, the present study mainly included respondents from urban areas and respondents from rural areas were not approached due to resources and time constraints. Therefore, the same topic could be investigated on the rural customers in Pakistan and elsewhere. Besides, the present study employed only the three categories of products i.e., food, cosmetics and fragrances; whereas, future studies may be carried out with a much more broader product ranges to ascertain the consumption patterns of people in terms of other product categories as well.

\section{REFERENCES}

Aaker, D. (1991). Managing brand equity: Capitalizing on the value of a brand name. New York, NY: The Free Press.

Aaker, D. (1996). Measuring brand equity across products and markets. California Management Review, 38(3), 102-120. doi: https://doi.org/10.2307/41165845

Ahmad, S., \& Butt, M. M. (2012). Can after sale service generate. Marketing Intelligence and Planning, 30(3), 307-323. doi: https://doi.org/10.1108/02634501211226285

Ahmed, W., Najmi, A., Faizan, H. M., \& Ahmed, S. (2019). Consumer behaviour towards willingness to pay for halāl products: An assessment of demand for halāl certification in a muslim country. British Food Journal, 121(2), 492-504. doi: https://doi.org/10.1108/BFJ-02-2018-0085 
Ajzen, I. (1991). Theory of planned behavior. Organziational Behavior and Human Decision Process, 50(2), 179-211. doi: https://doi.org/10.1016/0749-5978(91)90020-T

Alhyasat, K. (2010). The role of Islamic work ethics in developing organizational citizenship behavior at the Jordanian press foundations. Journal of Islamic Marketing, 3(2), 3-30.

Ali, A. R., Noorin, K. B., \& Achour, M. (2018). The Islamic approach of obligations in mutual relations between employee and employer. International Journal of Ethics and Systems, 34(3), 338-351 doi: https://doi.org/10.1108/IJOES-12-2017-0227

Ali, A., \& Al-Kazemi, A. (2007). Islamic work ethics in Kuwait. Cross Cultural Management: An International Journal, 14(2), 93-104.

doi: https://doi.org/10.1108/13527600710745714

Ali, A., Xiaoling, G., Sherwani, M., \& Ali, A. (2018). Antecedents of consumers' halāl brand purchase intention: An integrated approach. Management Decision, 56(4), 715735. doi: https://doi.org/10.1108/MD-11-2016-0785

Ali, J. (1992). Islamic work ethic in Arabia. Journal of Psychology, 126(5), 507-517. doi: https://doi.org/10.1080/00223980.1992.10543384

Al-Maududi, A. (1967). Islamic way of life. Karachi, Pakistan: Islamic Research Academy. Alserhan, B. (2010). Islamic branding: A conceptualization of related terms. Journal of Brand Management, 18(1), 34-49. doi: https://doi.org/10.1057/bm.2010.18

Ambali, A. R., \& Bakar, A. N. (2014). People's awarness on halāl foods and products: Potential issues for policy-makers. Social and Behavioral Sciences, 121, 3-25. doi: https://doi.org/10.1016/j.sbspro.2014.01.1104

Armitage, C. A. (2001). Efficacy of the theory of planned behaviour: A meta-analytic review. British Journal of Social Psychology, 40(4), 471-499.

doi: https://doi.org/10.1348/014466601164939

Asnawi, N., Sukoco, B. M., \& Fanani, M. A. (2018). Halāl products consumption in international chain restaurants among global moslem consumers. International Journal of Emerging Markets, 13(5), 1273-1290.

doi: https://doi.org/10.1108/IJoEM-11-2017-0495

Aziz, Y. A., \& Chok, N. V. (2012). The role of halāl awareness, halāl certification, and marketing components in determining haläl purchase intention among non-muslims in Malaysia: A structural equation modeling Approach. Journal of International Food and Agribusiness Marketing, 25(1), 1-23. doi: https://doi.org/10.1080/08974438.2013.723997

Bhattacharya, C. (2012). Leveraging corporate responsibility': The stakeholder approach to maximizing business and social value. Retrieved from https://whr.tn/2SSTuwk

Chaudhuri, A., \& Holbrook, M. B. (2001). The chain of effects from brand trust and brand affect to brand performance: The role of brand loyalty. Journal of Marketing, 65(2), 81-93. doi: https://doi.org/10.1509/jmkg.65.2.81.18255

Chaudry, M. M., \& Riaz, M. N. (2004). Halāal food production. Boca Raton, FL: CRC Press.

Cho, E., Fiore, A. M., \& Russell, D. W. (2015). Validation of a fashion brand image scale capturing cognitive, sensory, and affective associations: Testing its role in an extended brand equity model. Psychology and Marketing, 32(1), 28-48.

doi: https://doi.org/10.1002/mar.20762 
Dobni, D., \& Zinkhan, G. (1990). In search of brand image a foundation analysis. Advances in Consumer Research, 17, 110-119.

Esch, F.-R., Langner, T., Schmitt, B. H., \& Geus, P. (2006). Are brand forever? How brand knowledge and relationships affect current and future purchases. Journal of Product $\mathcal{E}$ Brand Management, 15(2), 98-105. doi: https://doi.org/10.1108/10610420610658938

Farquhar, P. (1989). Managing brand equity. Journal of Marketing Research, 1(3), 24-33.

Hashi, A. A. (2011). Islamic ethics: An outline of its principles and scope. Revelation and Science, 1(3), 122-130.

Heckler, S., Keller, K., Houston, M., \& Avery, J. (2014). Building brand knowledge structures: Elaboration and interference effects on the processing of sequeneially advertised brand benefit claims. Journal of Marketing Communicationis, 20(3), 176-196. doi: https://doi.org/10.1080/17544750.2012.660766

Illsley, C. (2018). Largest religions in the world. Retrieved from https://bit.ly/2P4bLG7

Ismaeel, M., \& Blaim, K. (2012). Toward applied Islamic business ethics: Responsible halāl business. Journal of Management Development, 31(10), 1090-1100. doi: https://doi.org/10.1108/02621711211281889

Jalil, A., Azam, F., \& Rahman, M. (2010). Implementation mechanism of ethics in business organizations. International Business Research, 5(2), 45-51.

doi: https://doi.org/10.5539/ibr.v3n4p145

Jenni, R, S. W., \& Faulkner, M. (2017). Brand awareness: Revisiting and old metric for a new world. Journal of Product and Brand Management, 26(5), 469-476.

doi: https://doi.org/10.1108/JPBM-06-2016-1242

Jeon, J.-E. (2017). The impact of brand concept on brand equity. Asia Pacific Journal of Innovation and Entrepreneurship, 11(2), 233-245.

doi: https://doi.org/10.1108/APJIE-08-2017-030

Kamal, H. (1985). Professionalism and Islamic work ethic (Professionalism and work ethics of Islam). In Islamic Management Seminar Paper, Universiti Putra Malaysia, Seri Kembangan, Malaysia

Kapferer, J. N. (2004). The new strategic brand management: Creating and sustaining brand equity long term (4th ed.). London, UK: Kogan Page.

Keller, K. (1993). Conceptualizing, measuring and managing customer-based brand equity. Journal of Marketing, 57(1), 1-22. doi: https://doi.org/10.1177/002224299305700101

Keller, K. (2008). Strategic brand management: Building, measuring and managing brand equity (3rd ed.). Englewood Cliffs, NJ: Prentice Hall.

Keller, K. L. (1993). Conceptualizing, measuring and managing customer-based brand equity. Journal of Marketing, 57(1), 1-22. doi: https://doi.org/10.1177/002224299305700101

Keller, K., \& Lehmann, D. (2003). How do brands create value? Marketing Management, 12(3), 27-31.

Khan, K. (2013).Organizational justice and job outcomes: Moderating role of Islamic work ethic. Journal of Business Ethics, 126(2), 235-246.

doi: https://doi.org/10.1007/s10551-013-1937-2 
Klobas, J. A. (2000). Adults learning to use the internet: A longitudinal study of attitudes and other factors associated with intended internet use. Library $\mathcal{E}$ Information Science Research, 22(1), 5-34. doi: https://doi.org/10.1016/S0740-8188(99)00038-9

Kotler, P, G. M. (2010). Principles of marketing (13th ed.). Upper Saddle River, NJ: Prentice Hall.

Lassar, W., Mittal, B., \& Sharma, A. (1995). Measuring customer-based brand equity. Journal of Consumer Marketing, 12(4), 11-19. doi: https://doi.org/10.1108/07363769510095270

Magid, J. M., \& Dena, S. (2006). Quantifying brand image: Empirical evidence of trademark dilution. American Business Law Journal, 43(1), 1-42.

doi: https://doi.org/10.1111/j.1744-1714.2009.01071.x

Mohammad, J., \& Quoquab, F. (2016). Furthering the thought of Islamic work ethic: How does it differ? Journal of Islamic Marketing, 7(3), 355-375.

doi: https://doi.org/10.1108/JIMA-07-2014-0047

Mutahhari, M. (1985). Fundamentals of Islamic thought: God, man and the universe. Berkeley, CA: Mizan Press.

Nandan, S. (2005). An exploration of the brand identity-brand image linkage: A communications perspective. Brand Management, 12(4), 264-278.

doi: https://doi.org/10.1057/palgrave.bm.2540222

Ngah, A. H., Zainuddin, Y., \& Thurasamy, R. (2014). Adoption of halāl supply chain among Malaysian halāl manufacturers: An exploratory study. Procedia-Social and Behavioral Sciences, 129, 388-395. doi: https://doi.org/10.1016/j.sbspro.2014.03.692

Owahian, A. A., \& Ali, A. (2008). Islamic work ethic: A critical review. Cross Cultural Management An International Journal, 15(1) 5-19.

doi: https://doi.org/10.1108/13527600810848791

Pettinger, C., Holdsworth, M., \& Gerber, M. (2004). Psycho-social influences on food choice in Southern France and Central England. Appetite, 42(3), 307-316. doi: https://doi.org/10.1016/j.appet.2004.01.004

Possumah, B. A. (2013). Bringing work back in Islamic ethics. Journal of Business Ethics, 112(2), 257-270. doi: https://doi.org/10.1007/s10551-012-1246-1

Pouromid, B., \& Iranzadeh, S. (2012). The evaluation of the factors affects on the brand equity of Pars Khazar household appliances based on the vision of female consumer. Middle-East Journal of Scientific Research, 12(8), 1050-1055.

Rahman, A. A., Asrahaghighi, E., \& Rahman, S. A. (2015). Consumers and halāl cosmetic products: Knowledge, religiosity, attitude and intention. Journal of Islamic Marketing, 6(1), 148-163. doi: https://doi.org/10.1108/JIMA-09-2013-0068

Rios, R. E., Riquelme, H. E., \& Abdelaziz, Y. (2014). Do halāl certification country of origin and brand name familiarity matter? Asia Pacific Journal of Marketing and Logistics, 26(5), 665-686. doi: https://doi.org/10.1108/APJML-03-2014-0046

Rory, P. M. (2000). A consumer oriented framework of brand equity and loyalty. International Journal of Research in Marketing, 42(1), 65-78. doi: https://doi.org/10.1177/147078530004200105 
Rosly, A. (2010). Shariah parameters reconsidered. International Journal of Islamic and Middle Eastern Finance and Management, 3(2), 133-146.

doi: https://doi.org/10.1108/17538391011054372

Rossiter, J., \& Percy, L. (1987). Advertising and promotion management (1st ed.). New York, NY: McGraw-Hill.

Sallam, M. A. (2016). The impact of brand image and corporate branding on consumer's choice: The role of brand equity. International Journal of Marketing Studies, 8(1), 98-106. doi: https://doi.org/10.5539/ijms.v8n1p98

Sasmita, J., \& Suki, N. M. (2015). Young consumers' insights on brand equity effects of brand association, brand loyalty, brand awareness and brand image. International Journal of Retail and Distribution Management, 43(3), 276-292. doi: https://doi.org/10.1108/IJRDM-02-2014-0024

Severi, E., \& Ling, K. C. (2013). The mediating effects of brand association, brand loyalty, brand image and perceived quality on brand equity. Asian Social Science, 9(3), 125-137. doi: https://doi.org/10.5539/ass.v9n3p125

Shafie, S., \& Othman, M. (2006). Halāl certification: An international marketing issues and challenges. Retrieved from https://bit.ly/3bMZeAF

Shahid, S., Ahmed, F., \& Hasan, U. (2018). A qualitative investigation into consumption of halāl cosmetic products: The evidence from India. Journal of Islamic Marketing, 9(3), 484-503. doi: https://doi.org/10.1108/JIMA-01-2017-0009

Sherry, J. (2005). Brand Meaning. In A. M. Tybout and T. Calkins, Kellogg on branding: The marketing faculty of the Kellogg school of management. Hoboken, NJ: John Wiley $\&$ Sons.

Siala, H. (2013). Religious influences on consumers' high-involvement purchasing decisions. Journal of Services Marketing, 27(7), 579-589. doi: https://doi.org/10.1108/JSM-022012-0046

Suki, N. M., \& Salleh, A. S. (2017). Mediating effect of halāl image on Muslim consumers' intention to patronize retail stores: Some insights from Malaysia. Journal of Islamic Marketing 9(2), 338-355.

doi: https://doi.org/10.1108/JIMA-02-2017-0014

Sungkar, I. (2010). Consumer awareness: Thoughts and trends across the globe. The Halāl Journal 2(1), 22-28.

Tarkiainen, A., \& Sundqvist, S. (2005). Subjective norms, attitudes and intentions of finish consumers in buying organic food. British Food Journal, 107(11), 808-822. doi: https://doi.org/10.1108/00070700510629760

Waller, D., Fam, K.-S., \& Erdogan, Z. (2005). Advertising of controversial products: A cross-cultural study of consumer marketing. Journal of Conusmer Marketing, 22(1), 6-13. doi: https://doi.org/10.1108/07363760510576509

Wibowoa, M. (2005). Non-muslim consumer's halāl food acceptance model. Procedia Economics and Finance, 37, 276-283. doi: https://doi.org/10.1016/S2212-5671(16)30125-3

Wilson, R. (2006). Islam and business. Thunderbird International Business Review, 48(1), 109-123. doi: https://doi.org/10.1002/tie.20088 
Wilson. (2013). Halāl value system, Changing world, new relationships. 9th World Islamic Economic Forum, Price water house Coopers (PwC), Kuala Lumpur, Malaysia.

Yoo, B., \& Donthu, N. (2001). Developing and validating a multidimensional consumerbased brand equity scale. Journal of Business Research, 52(1), 1-14. doi: https://doi.org/10.1016/S0148-2963(99)00098-3

Zul Kernain, N., \& Norhasniah, W. (2019). The influence of individual behaviour and organizational commitment towards the enhancement of Islamic work ethics at royal Malaysian air force. Journal of Business Ethics, (Accepted article), 1-11. 